\title{
Genetic and ecological differentiation between the butterfly sisterspecies Colias alfacariensis and Colias hyale
}

\author{
Daniel F.R. Cleary ${ }^{1}$, Henri Descimon ${ }^{2}$ and Steph B.J. Menken ${ }^{1}$ \\ IInstitute for Biodiversity and Ecosystem Dynamics (IBED), Faculty of Science, University of Amsterdam, \\ P.O. Box 94766, 1090 GT Amsterdam,The Netherlands, cleary@science.uva.nl; \\ ${ }^{2}$ Laboratoire de Systématique Évolutive, Université de Provence, Marseille, France
}

Keywords: Lepidoptera, Pieridae, allozymes, population structure, gene flow

\begin{abstract}
Clear habitat separation between the sister species Colias alfacariensis and $C$. hyale is shown when occurring sympatrically. Colias hyale is found more often in moist cultivated pastures while Colias alfacariensis is more abundant in dry uncultivated habitat. Out of a total of 16 loci, no diagnostic loci were found

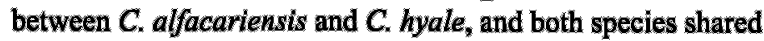
most major polymorphisms. Exceptions were the marked differences in allele frequencies at the HK locus and only $C$. hyale, but not $C$, alfacariensis was further invariable at the GOT2 locus, which is usually highly polymorphic in the Pieridae. Colias hyale has a significantly lower level of heterozygosity than its sister species $C$. alfacariensis. In Colias alfacariensis heterozygosity is highest in the Alps and lowest in the low-lying region of Northern France. Both species show high levels of gene flow over a large geographic area. Within $C$. alfacariensis, but not in $C$. hyale, the $\mathrm{F}_{\mathrm{ST}}$ value of the $\mathrm{PGI}$ locus is significantly different from zero effectively separating the species into populations with high levels of the ' $b$ ' allele to the west and North, and low levels of the allele in the Alps and Italy. This could point to selection within the PGI locus in line with the well established pattern of selection at the PGI locus in other species of Colias. Glaciations have been an important force in shaping the evolutionary history of European biota, leading to extinction, but also allowing new species to evolve into the newly available land as the ice sheets retreated. The genetic and distributional pattern found between both Colias species suggests that habitat shifts and subsequent adaptation during glaciations could have played an important role in their speciation.
\end{abstract}

\section{Contents}

Introduction

Material and methods Habitat preference Population analysis

\author{
Habitat preference \\ Population analysís \\ Díscussíon \\ Acknowledgements \\ References
}

134

134

136

138

138

\section{Introduction}

Coexistence of species requires the existence of evolutionarily continual interspecific trade-offs in the abilities of species to deal with factors that limit their fitness and abundance. These include tradeoffs between competitive abilities and dispersal abilities, susceptibility to disease, herbivory or predation, between abilities to live off average conditions or abilities to exploit resource pulses, and between abilities to compete for alternative resources in a heterogeneous landscape (Tilman, 2000). Feeding ecology, reproductive behaviour, and physiology are characteristics of a species niche. Niches tend to be conservative over time scales associated with sister taxon pairs in, for example, birds, mammals, and butterflies but this conservatism breaks down at the level of families (Peterson et al, 1999). By analysing the present day difference in genetic makeup and the often subtle differences in ecology between species within a pair of sister species we can get an idea of the evolutionary forces that led to their differentiation into separate species.

The present study concerns two species of the genus Colias [Lepidoptera: Pieridae] namely $C$. alfacariensis and C. hyale (Brunton, 1998). Colias is one of the most widespread butterfly genera in the world. It is present on all continents except 
Australia, and ranges from the Antarctic (e.g., Colias antarctica) to the Arctic (e.g., Colias boothi), across Asia, Africa, North and South America, from the lowlands to the highest mountains.

Colias alfacariensis and C. hyale are sister species (Brunton, 1998), and are difficult to tell apart due to the large variation in wing patterns and other morphological characters of the butterflies. In general, $C$. hyale has a more northerly and $C$. alfacariensis a more southerly distribution with a large region of overlap in central Europe. In recent years C. hyale has become increasingly rare in northern Europe due to abandonment in agricultural areas of its larval food plant Medicago sativa (Descimon, (1994(5)).

Colias alfacariensis flies in May-June and August-September in two, and in southern Europe sometimes in three generations. Food plants are Hippocrepis comosa and Coronilla varia. Colias hyale has similar flight periods and the food plants are Medicago sativa, Vicia cracca, Coronilla spp., Lotus spp., Cytisus spp., Trifolium spp., and other Fabaceae (Higgins and Riley, 1970). Both species are thus oligophagous on Fabaceae although C. hyale has a larger range of potential food plants.

The goal of this study is to analyse the ecology and genetical population structure of both species and to try to gain insight into the differentiation process that produced both present-day taxa. Lepidoptera are an important source for understanding the genetics of speciation (Menken et al., 1992; Ritchie and Phillips, 1998). The analysis of spatial pattern (e.g., relative densities and habitat preferences), direct measures of migration (e.g., Markrelease-recapture), and indirect measures (e.g., genetic differentiation) are all important for understanding how populations are structured. Lewis et al. (1997; and refs therein) suggest that at least two of these methods should be applied in order to provide a good indication of population structure.

The specific questions we address are the following. 1) Do both species differ in their habitat preference? 2) What is the spatial, genetical population structure of both species?
Materials and methods

\section{Habitat preference}

Individuals of both $C$. alfacariensis and $C$. hyale were sampled for an allozyme study in France and Italy in the summer of 1992. Species determination was based on the studies of Berger and Fontaine (1947), Jarvis (1955), and Dutreix (1980). Habitat preference between $C$. alfacariensis and $C$. hyale was studied by means of field observations in the French Alps where both species occur sympatrically.

A total of 920 adult $C$. alfacariensis and 1155 adult $C$. hyale were observed from the $14^{\text {th }}$ of $\mathrm{Au}$ gust until the $8^{\text {th }}$ of September, 1974 by HD. The location and geographical position of all sites is presented in Table 1. During the field observations the following environmental variables were noted at each locality: 1. Aspect, 2. Vegetation (cultivated - uncultivated), 3. Humidity (dry - irrigated), 4. Altitude 5. Date, 6. Weather (warm - cold), in addition to the frequency of occurrence of adults of C. alfacariensis and C. hyale.

The relative abundances of both species were regressed onto the first axis of a principal components analysis (PCA based on the environmental variables and using Statistica for Windows, version 5, StatSoft Inc.) to see if both species varied significantly (positively or negatively) in their response to this synthetic environmental gradient. The relative abundance here is the absolute abundance of species $\mathrm{A}$ at a given site divided by the absolute abundances of both species at the same site. We use relative abundance here because of the high variance in the absolute abundance among sites.

\section{Population analysis}

For the allozyme electrophoresis analyses, populations of both Colias species were sampled in the French Alps and other localities, including the Provence, Northern France and Italy (Table 1). After capture the butterflies were stored in liquid nitrogen. The head and thorax were subsequently homogenised in the laboratory in $180 \mathrm{ml}$ of a $0.1 \mathrm{M}$ Tris-HCl buffer ( $\mathrm{pH} \mathrm{8.0)}$ and the extracts were cen- 
Table 1. Location and geographical position of all sampling sites. Allozyme indicates that the population sampled was used in allozyme electrophoretic analysis. Field indicates that the site was used in the habitat preference study. The two populations from northern France were collected by a colleague in the surroundings of Paris and Metz. Population refers to the populations used for electrophoresis. A - J: C. alfacariensis, $\mathrm{K}-\mathrm{M}$ : C. hyale.

\begin{tabular}{|c|c|c|c|c|c|c|}
\hline Population & Site $" A$ & Location & Lat & Long & Allozyme & Fïeld \\
\hline A & Poggio del Commune & Italy & 4457.64 & 641.01 & $\mathbf{x}$ & \\
\hline $\mathbf{B}+\mathbf{M}$ & Val de Prés & French Alps & 4458.47 & 630.33 & $\mathbf{x}$ & $\mathbf{x}$ \\
\hline $\mathrm{C}+\mathrm{L}$ & Le Monêtier les Bains & French Alps & 4453.52 & 637.02 & $\mathbf{x}$ & $\mathbf{x}$ \\
\hline D & Puy Saint Pierre & French Alps & 4453.52 & 637.02 & $\mathbf{x}$ & \\
\hline $\mathbf{E}$ & Saint Zachery & French Alps & 4323.07 & 542.22 & $\mathbf{x}$ & \\
\hline F & Pontèves & Provence & 4333.55 & 602.53 & $\mathbf{x}$ & \\
\hline G & Artigues & Provence & 4336.05 & 547.54 & $\mathbf{x}$ & \\
\hline H & Mímet & Provence & 4324.54 & 530.19 & $\mathbf{x}$ & \\
\hline I & Seine Rivver outside Paris & Provence & & & $\mathbf{x}$ & \\
\hline \multirow[t]{11}{*}{$\mathrm{J}+\mathrm{K}$} & Surroundings of Metz & Northern France & & & $\mathbf{x}$ & \\
\hline & Gero & Northern France & 4459.03 & 628.56 & & $\mathbf{x}$ \\
\hline & les Guibertes & French Alps & 4458.01 & 631.57 & & $\mathbf{x}$ \\
\hline & le Cassset & French Alps & 4459.03 & 628.56 & & $\mathbf{x}$ \\
\hline & Saint Chaffery & French Alps & 4455.32 & 636.11 & & $\mathbf{x}$ \\
\hline & le Rosier & French Alps & 4456.02 & 640.58 & & $\mathbf{x}$ \\
\hline & Villard Saint Pancrace & French Alps & 4452.09 & 638.05 & & $\mathbf{x}$ \\
\hline & la Vachette & French Alps & 4454.58 & 639.55 & & $\mathrm{x}$ \\
\hline & Laus de Cervières & French Alps & 4451.40 & .643 .35 & & $\mathbf{x}$ \\
\hline & Granon & French Alps & 4458.04 & 639.01 & & $\mathbf{x}$ \\
\hline & Cervières & French Alps & 4451.56 & 643.21 & & $\mathbf{x}$ \\
\hline
\end{tabular}

trifuged for 6 minutes at $9000 \times \mathrm{g}$. The supernatant from the extract was then frozen until used for electrophoresis.

Two gel matrices were used, namely cellulose acetate and starch gels. The starch gels were prepared according to Harris and Hopkinson (1977) and the exact preparation of buffers and gels follows Raijmann et al. (1997). Two buffer solutions were used in the starch gels, namely a Tris-Citric acid buffer (TC 8.0) and a Tris-Malic acid buffer (TM 7.4). Agar overlays were applíed to all gel slices.

The following loci (locus abbreviations in parentheses) gave consistently good results and were used for the analyses: Aldolase (ald), Creatine Kinase $1(c k l)$ and 2 (ck2), Glutamate-oxaloacetate transaminase 1 (got l) and 2 (got2), Glycerol-3phosphate dehydrogenase ( $g p d)$, Hexokinase $(h k)$, Isocitrate dehydrogenase 1 (idhl) and 2 (idh2), Malate dehydrogenase 1 ( $m d h I)$ and 2 (mdh2), Malic enzyme (me), Mannose phosphate isomerase ( $m p i)$, Phosphogluconate dehydrogenase ( $6 \mathrm{pgdh}$ ), Glucose. phosphate isomerase (pgi), and Phosphoglucomutase (pgm). The loci $c k 1, c k 2$, gpd, got2, and pgm gave the best resolution with TM; gotl, $h k, m d h 1$, $m d h 2, m e, m p i, i d h 1, i d h 2$, and $p g i$ gave the best resolution with $\mathrm{TC} ; 6 p g d h$ gave the best resolution with a Tris-Glycine buffer ( $\mathrm{pH} \mathrm{8.5)}$ on cellulose acetate. Locus number 1 refers to the least anodally migrating locus. Allelic designations use " $a$ " as the least anodally migrating allele, then ' $b$ ' and so forth.

Individual genotypes were used as input data for BIOSYS-1 (Swofford and Selander, 1981). The allelic frequencies and mean heterozygosity were derived directly from the BIOSYS output. Variation in heterozygosity between C. alfacariensis and C. hyale was tested for significance with a oneway Anova (using Statistica for Windows, version 5, StatSoft Inc.).

The inbreeding coefficients $\left(\mathrm{F}_{\mathrm{ST}}, \mathrm{F}_{\mathrm{IT}}\right.$, and $\mathrm{F}_{\mathrm{IS}}$; Wright, 1951) were calculated according to Weir and Cockerham's (1984) F, f, and Theta respectively. $F_{\mathrm{ST}}$ values were tested for departure from zero by the method of Workman and Niswander (1970), and inbreeding coefficients $\left(F_{\text {IS }}\right)$ were tested by the method of Li and Horvitz (1953).

The amount of gene flow $\left(\mathrm{N}_{\mathrm{e}} \mathrm{m}\right)$ was estimated 
by the $\mathrm{F}$ statistic $\left(\mathrm{F}_{\mathrm{ST}}\right)$ method of Weir and Cockerham (1984), which uses Theta as an estimate of $\mathrm{F}_{\mathrm{ST}}$. Theta is assumed to be a better estimate of $\mathrm{F}_{\mathrm{ST}}$ than Wright (1978) estimate and does not make assumptions about number of populations, sample sizes, or heterozygote frequencies so that it is more appropriate for small data sets (Weir and Cockerham, 1984). $\mathrm{F}_{\mathrm{ST}}$ values were calculated using the computer programme THETA (Ellis, 1994), which uses the individual genotypes as input. $F_{S T}$ is a useful estimator of gene flow according to the equation $\mathrm{N}_{\mathrm{e}} \mathrm{m} \approx-\left(\left[1 / \mathrm{F}_{\mathrm{ST}}\right]-1\right)$ (Wright, 1951). Since there is an inverse relationship between $\mathrm{F}_{\mathrm{ST}}$ and $\mathrm{N}_{\mathrm{e}} \mathrm{m}$ we consider $\mathrm{F}_{\mathrm{ST}}$ values that do not differ significantly from zero to indicate unlimited gene flow, i.e., a panmictic populations structure.

\section{Results}

\section{Habitat preference}

Along the synthetic environmental axis (PCA-1) C. australis has a highly significant $\left(\mathrm{R}^{2}=0.599\right.$, $\mathrm{F}_{1,33}=49.20, \mathrm{P}<0.001$ ) positive relation to $\mathrm{PCA}-$ 1 whereas $C$. hyale has a highly significant $\left(\mathrm{R}^{2}=\right.$ $0.599, \mathrm{~F}_{1.33}=49.24, \mathrm{P}<0.001$ ) negative relation (Fig. 1). Of the six environmental variables, vegetation and altitude were positively correlated with PCA-1, aspect and humidity negatively correlated, and date and weather uncorrelated. Humidity is thus probably the most important environmental determinant of both species since there is an obvious

\section{Environmental Relation}

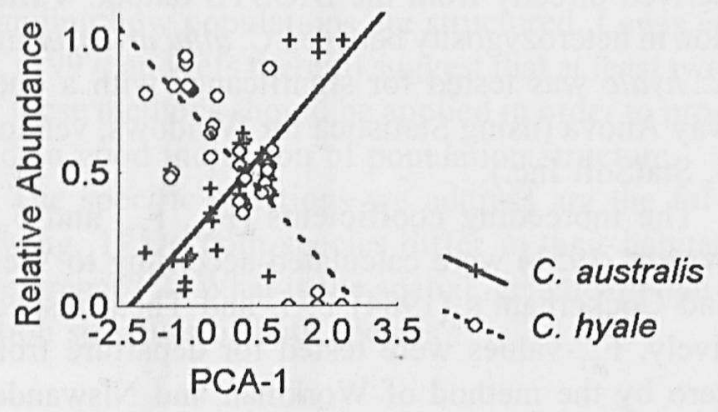

Fig. 1. Regression of $C$. alfacariensis and $C$. hyale onto the first Principal component axis (PCA-1). The slope of both lines is highly significant $(P<0.001)$. relation (e.g., exposed ridges tend to be drier than valley bottoms) between humidity and the other three variables that had high loadings for PCA-1 (vegetation, altitude, and aspect).

\section{Population analysis}

Four of the loci (ald, $m d h 1, c k 2$, and got l) are monomorphically fixed for the same allele in the populations of both species. The remaining set of 12 allozyme loci did not contain loci that were diagnostic between $C$. alfacariensis and $C$. hyale (Appendix I). Four loci (got2, mpi, pgi, and pgm) show a very high degree of genetic polymorphism, but got 2 is monomorphic in all populations of $C$. hyale. An intermediate level of genetic polymorphism is found among the loci $h k$, idhl, and me. Low levels of genetic variability are present in the remaining loci (Appendix 1).

In general, $C$. alfacariensis tends to have both a higher mean number of alleles and percentage of polymorphic loci (Table 2). Consequently, Colias alfacariensis also has a significantly higher heterozygosity (range: $0.148-0.194$ ) than $C$. hyale (range: 0.084-0.094) $\left(\mathrm{F}_{1,11}=72.70, \mathrm{P}<0.001\right)$. Heterozygosity is highest for $C$. alfacariensis populations in the geographically complex Alps and drops off towards the lower-lying regions to the South (Provence and Italy) and the North (Metz and Seine), with the lowest values occurring in Northern Europe. Within C. alfacariensis, the Alpine/Italian on the one hand and the Provence/Northern populations on the other hand consistently differ at the PGI locus (Fig. 2).

In $C$. alfacariensis, estimated single locus $\mathrm{F}_{\text {IS }}$ significantly differs from zero at me (Table 3 ). In C. hyale the PGM locus significantly differs from zero. $\mathrm{F}_{\mathrm{IS}}$ values were generally slightly positive in both species indicating a small deficiency of heterozygotes. In both species total genetic diversity $\left(\mathrm{F}_{\mathrm{IT}}\right)$ was mainly the result of inbreeding $\left(\mathrm{F}_{\mathrm{IS}}\right)$, among population variation $\left(\mathrm{F}_{\mathrm{ST}}\right)$ being less important. Within populations of both species the most common allele at a locus is usually the same (Appen$\operatorname{dix} 1$ ). Within $C$. hyale none of the loci have a $\mathrm{F}_{\mathrm{ST}}$ value significantly different from zero indicating that, at least until recently, there was a panmictic 
Appendix 1: Allele frequencies for all populations (coded by letters $A$ to $M$ as in Table 1) are given at 12 polymorphic loci. Letters $A$ to $\mathrm{J}$ are populations of $C$. alfacariensis, letters $\mathrm{K}$ to $\mathrm{M}$ are populations of $C$. hyale as in Table 1 .

\begin{tabular}{|c|c|c|c|c|c|c|c|c|c|c|c|c|c|c|}
\hline Locus & & $\mathbf{A}$ & B & c & D & E & F & G & H & I & $\mathrm{J}$ & $\mathbf{K}$ & L & $\mathbf{M}$ \\
\hline \multirow[t]{2}{*}{$c k I$} & $a$ & - & $\mathrm{E}^{*}$ & 0.026 & 0.056 & - & - & 0.036 & $=$ & 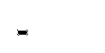 & - & 0.022 & - & - \\
\hline & $b$ & 1.000 & 1.000 & 0.974 & 0.944 & 1.000 & 1.000 & 0.964 & 1.000 & 1.000 & 1.000 & 0.978 & 1.000 & 1.000 \\
\hline \multirow[t]{5}{*}{ got2 } & $a$ & $=$ & - & - & - & 0.023 & - & - & - & - & - & - & $=$ & - \\
\hline & $b$ & 0.079 & 0.063 & - & - & 0.045 & 0.024 & 0.036 & - & - & - & - & - & - \\
\hline & $c$ & 0.263 & 0.250 & 0.211 & 0.333 & 0.318 & 0.429 & 0.357 & 0.500 & 0.547 & 0.292 & - & - & $=$ \\
\hline & $d$ & 0.632 & 0.688 & 0.711 & 0.667 & 0.545 & 0.548 & 0.607 & 0.500 & 0.453 & 0.583 & 1.000 & 1.000 & 1.000 \\
\hline & $e$ & 0.026 & - & 0.079 & $=$ & 0.068 & $=$ & $=$ & - & - & 0.125 & $=$ & $=$ & - \\
\hline \multirow[t]{2}{*}{$g p d$} & $a$ & 0.026 & - & - & = & - & - & - & 0.071 & 0.016 & - & 0.022 & $=$ & $=$ \\
\hline & $b$ & 0.974 & 1.000 & 1.000 & 1.000 & 1.000 & 1.000 & 1.000 & 0.929 & 0.984 & 1.000 & 0.978 & 1.000 & 1.000 \\
\hline \multirow[t]{2}{*}{$h k$} & $a$ & 0.921 & 0.688 & 0.895 & 0.889 & 0.977 & 1.000 & 0.893 & 0.929 & 0.828 & 0.917 & - & . & $=$ \\
\hline & $b$ & 0.079 & 0.313 & 0.105 & 0.111 & 0.023 & - & 0.107 & 0.071 & 0.172 & 0.083 & 1.000 & 1.000 & 1.000 \\
\hline \multirow[t]{3}{*}{$i d h 1$} & $a$ & - & - & 0.079 & 0.056 & 0.068 & - & 0.107 & 0.000 & 0.078 & 0.042 & 0.022 & $=$ & $=$ \\
\hline & $b$ & 1.000 & 1.000 & 0.921 & 0.944 & 0.909 & 1.000 & 0.857 & 1.000 & 0.906 & 0.958 & 0.978 & 1.000 & 0.975 \\
\hline & $c$ & - & - & - & - & 0.023 & - & 0.036 & = & 0.016 & $=$ & $=$ & - & 0.025 \\
\hline \multirow[t]{3}{*}{$i d h 2$} & $a$ & - & 0.063 & - & - & 0.023 & - & 0.036 & - & - & - & $=$ & - & $=$ \\
\hline & $b$ & 1.000 & 0.938 & 0.974 & 1.000 & 0.955 & 1.000 & 0.929 & 1.000 & 1.000 & 1.000 & 1.000 & 0.958 & 0.950 \\
\hline & $c$ & - & - & 0.026 & - & 0.023 & - & 0.036 & * & - & $=$ & - & 0.042 & 0.050 \\
\hline \multirow[t]{3}{*}{$m d h 2$} & $a$ & - & - & 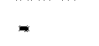 & - & - & 0.024 & $=$ & - & - & . & 0.022 & $=$ & - \\
\hline & $b$ & 0.947 & 1.000 & 0.974 & 0.889 & 1.000 & 0.929 & 1.000 & 1.000 & 0.953 & 0.958 & 0.978 & 1.000 & 0.975 \\
\hline & $c$ & 0.053 & - & 0.026 & 0.111 & - & 0.048 & - & - & 0.047 & 0.042 & - & - & 0.025 \\
\hline \multirow[t]{3}{*}{ me } & $a$ & . & $=$ & 0.053 & $=$ & - & $=$ & - & $=$ & $=$ & - & - & 0.042 & 0.025 \\
\hline & $\boldsymbol{b}$ & 0.921 & 0.938 & 0.789 & 0.889 & 0.841 & 0.905 & 0.857 & 0.929 & 0.953 & 0.958 & 1.000 & 0.958 & 0.975 \\
\hline & $c$ & 0.079 & 0.063 & 0.158 & 0.111 & 0.159 & 0.095 & 0.143 & 0.071 & 0.047 & 0.042 & - & $=$ & - \\
\hline \multirow[t]{6}{*}{$m p i$} & $a$ & $=$ & $=$ & 0.079 & 0.111 & 0.023 & 0.048 & 0.036 & $=$ & $=$ & - & - & $=$ & $=$ \\
\hline & $b$ & 0.289 & 0.375 & 0.342 & 0.389 & 0.455 & 0.190 & 0.429 & 0.214 & 0.328 & 0.542 & 0.109 & 0.167 & 0.050 \\
\hline & $c$ & 0.026 & - & $=$ & - & - & - & $=$ & 0.143 & - & - & $=$ & $=$ & $=$ \\
\hline & $d$ & 0.605 & 0.563 & 0.500 & 0.389 & 0.409 & 0.357 & 0.429 & 0.571 & 0.672 & 0.333 & 0.826 & 0.750 & 0.750 \\
\hline & $e$ & 0.053 & 0.063 & 0.079 & 0.056 & 0.114 & 0.286 & 0.071 & 0.071 & - & 0.083 & 0.065 & 0.083 & 0.150 \\
\hline & $f$ & 0.026 & - & - & 0.056 & - & 0.119 & 0.036 & - & - & 0.042 & - & - & 0.050 \\
\hline \multirow{3}{*}{ 6pgdh } & $a$ & 0.026 & $=$ & $=$ & - & $=\ldots$ & $=$ & 0.036 & . & . & $=$ & = & $=$ & - \\
\hline & $b$ & 0.974 & 1.000 & 1.000 & 1.000 & 1.000 & 1.000 & 0.964 & 1.000 & 1.000 & 1.000 & 0.978 & 1.000 & 1.000 \\
\hline & $c$ & $=$ & $=$ & - & $=$ & $=$ & $=$ & - & - & $=$ & $=$ & 0.022 & $=$ & $=$ \\
\hline \multirow[t]{5}{*}{$p g i$} & $a$ & 0.132 & 0.063 & 0.000 & 0.000 & 0.091 & 0.143 & 0.036 & 0.143 & 0.109 & 0.125 & 0.022 & 0.000 & 0.025 \\
\hline & $b$ & 0.263 & 0.125 & 0.105 & 0.222 & 0.591 & 0.643 & 0.536 & 0.571 & 0.656 & 0.708 & 0.457 & 0.417 & 0.475 \\
\hline & $c$ & 0.316 & 0.375 & 0.553 & 0.444 & 0.318 & 0.190 & 0.393 & 0.286 & 0.234 & 0.167 & 0.500 & 0.458 & 0.450 \\
\hline & $d$ & 0.289 & 0.375 & 0.342 & 0.333 & - & 0.024 & 0.036 & - & - & $=$ & 0.022 & 0.125 & 0.050 \\
\hline & $e$ & - & 0.063 & - & - & $=$ & $=$ & - & - & - & - & $=$ & $=$ & - \\
\hline \multirow[t]{7}{*}{ pgm } & $a$ & 0.053 & $=$ & 0.026 & $=$ & 0.023 & 0.024 & - & 0.071 & 0.016 & $=$ & 0.022 & - & 0.025 \\
\hline & $b$ & $=$ & - & - & - & $=$ & $=$ & - & - & 0.016 & - & $=$ & - & $=$ \\
\hline & $c$ & 0.053 & 0.125 & 0.079 & 0.056 & 0.045 & - & 0.036 & 0.071 & $=$ & 0.042 & $=$ & 0.042 & 0.100 \\
\hline & $d$ & 0.421 & 0.188 & 0.395 & 0.333 & 0.386 & 0.238 & 0.321 & 0.143 & 0.313 & 0.458 & 0.217 & 0.208 & 0.275 \\
\hline & $e$ & $=$ & $=$ & - & $=$ & 0.045 & $=$ & - & - & 0.047 & - & $=$ & - & - \\
\hline & $f$ & 0.421 & 0.688 & 0.500 & 0.611 & 0.477 & 0.667 & 0.643 & 0.714 & 0.547 & 0.500 & 0.717 & 0.708 & 0.575 \\
\hline & $g$ & 0.053 & $=$ & $=$ & $=$ & 0.023 & 0.071 & $=$ & $=$ & 0.063 & - & 0.043 & 0.042 & 0.025 \\
\hline
\end{tabular}

population structure with high levels of gene flow. Over the same geographic range, $C$. alfacariensis has an estimated $\mathrm{N}_{\mathrm{e}} \mathrm{m}$ of less than 10. The difference here though is solely due to the PGI locus, which effectively divides the species into a North-
em-Provence and Alpen-Italian component. Excluding this locus gives a panmictic population structure, since none of the other loci differ significantly from zero, quite similar to its sister species. 
Table 2. Population genetics summary statistics at 12 loci in all populations (standard errors in parentheses).

\begin{tabular}{|c|c|c|c|c|c|}
\hline Species & Population & $\begin{array}{l}\text { Sample } \\
\text { size per } \\
\text { Locus }\end{array}$ & $\begin{array}{l}\text { Mean no. } \\
\text { of alleles } \\
\text { per locus }\end{array}$ & $\begin{array}{l}\text { Percentage } \\
\text { of loci } \\
\text { polymorphic* }\end{array}$ & $\begin{array}{l}\text { Mean } \\
\text { heterozygosity } \\
\text { Direct-count }\end{array}$ \\
\hline C. australis & A & 19 & $2,2 \pm 0.4$ & 56.3 & $0.17 \pm 0.062$ \\
\hline C. australis & B & 8 & $1.8 \pm 0.3$ & 43.8 & $0.19 \pm 0.073$ \\
\hline C. australis & C & 19 & $2.1 \pm 0.3$ & 62.5 & $0.19 \pm 0.061$ \\
\hline C. australis & D & 9 & $1.9 \pm 0.3$ & 56.3 & $0.19 \pm 0.059$ \\
\hline C. australis & $\mathbf{E}$ & 22 & $2.3 \pm 0.4$ & 50.0 & $0.17 \pm 0.057$ \\
\hline C. australis & $\mathbf{F}$ & 21 & $1.9 \pm 0.3$ & 37.5 & $0.16 \pm 0.066$ \\
\hline C. australis & $\mathbf{G}$ & 14 & $2.2 \pm 0.3$ & 62.5 & $0.17 \pm 0.052$ \\
\hline C. australis & $\mathbf{H}$ & 7 & $1.8 \pm 0.3$ & 43.8 & $0.2 \pm 0.077$ \\
\hline C. australis & $\mathbf{I}$ & 32 & $1.9 \pm 0.3$ & 56.3 & $0.15 \pm 0.049$ \\
\hline C. australis & $\mathbf{J}$ & 12 & $1.8 \pm 0.2$ & 50.0 & $0.16 \pm 0.058$ \\
\hline C. australis & Mean & & 2.0 & 51.9 & 0.175 \\
\hline & & & & & \\
\hline C. hyale & $\mathbf{K}$ & 23 & $1.8 \pm 0.3$ & 50.0 & $0.08 \pm 0.04$ \\
\hline C. hyale & $\mathrm{L}$ & 12 & $1.6 \pm 0.2$ & 31.3 & $0.09 \pm 0.046$ \\
\hline C. hyale & $\mathbf{M}$ & 20 & $1.9 \pm 0.3$ & 43.8 & $0.08 \pm 0.039$ \\
\hline C. hyale & Mean & & 1.8 & 41.7 & 0.087 \\
\hline
\end{tabular}

* A locus is considered polymorphic if the frequency of the most common allele does not exceed 0.990

Table 3. Estimates of Wrights $\mathrm{F}$-statistics $\left(\mathrm{F}_{\mathrm{IS}}, \mathrm{F}_{\mathrm{ST},}\right.$ and $\left.\mathrm{F}_{\mathrm{rT}}\right)$ at 12 allozyme loci for $C$ alfacariensis and $C$. hyale.

\begin{tabular}{|c|c|c|c|c|c|c|}
\hline \multirow[b]{2}{*}{ Locus } & \multicolumn{3}{|c|}{ Collas australis } & \multicolumn{3}{|c|}{ Colias hyale } \\
\hline & $\mathbf{F}_{\text {ST }}$ & $\mathbf{F}_{\mathrm{IT}}$ & $\mathbf{F}_{\text {IS }}$ & $\mathrm{F}_{\mathrm{ST}}$ & $\mathbf{F}_{\text {IT }}$ & $F_{\text {IS }}$ \\
\hline ckl & 0.003 & -0.006 & -0.009 & -0.009 & -0.003 & 0.006 \\
\hline got2 & 0.018 & 0.015 & -0.003 & - & - & $=$ \\
\hline gpd & 0.002 & -0.006 & -0.008 & -0.009 & -0.003 & 0.006 \\
\hline$h k$ & 0.035 & 0.175 & 0.145 & - & $=$ & $=$ \\
\hline idhI & 0.010 & -0.049 & -0.059 & -0.013 & -0.009 & 0.004 \\
\hline$i d h 2$ & 0.004 & -0.010 & -0.014 & 0.004 & -0.017 & -0.022 \\
\hline$m d h 2$ & 0.007 & 0.140 & 0.146 & -0.013 & -0.009 & 0.004 \\
\hline$m e$ & 0.007 & 0.219 & $0.225^{* * *}$ & -0.004 & -0.011 & -0.006 \\
\hline$m p i$ & 0.027 & 0.176 & 0.153 & -0.014 & 0.265 & 0.275 \\
\hline 6pgdh & 0.003 & -0.003 & 0.000 & -0.009 & -0.003 & 0.006 \\
\hline$p g i$ & $0.120 * * *$ & 0.122 & 0.003 & -0.022 & 0.007 & 0.029 \\
\hline pgm & 0.000 & 0.088 & 0.088 & -0.016 & 0.350 & $0.360 * *$ \\
\hline Global & 0.037 & 0.107 & 0.073 & -0.016 & 0.167 & 0.180 \\
\hline Average & $0.029(0.011)$ & $0.098(0.022)$ & 0.071 & $-0.023(0.008)$ & $0.158(0.050)$ & $0.177(3.862)$ \\
\hline
\end{tabular}

Significant departures from zero: **: $\mathrm{P}<0.01$; *** $\mathrm{P}<0.001$. Average and (standard deviation) obtained by a bootstrap procedure over samples (1000 repeats).

\section{Discussion}

Colias alfacariensis and $C$. hyale both have a pronounced habitat preference, with $C$. hyale found on moist cultivated areas and C. alfacariensis found on dry uncultivated areas. Colias hyale has a consistently lower level of heterozygosity than C. alfa- cariensis, has fewer alleles per locus, and most populations are monomorphic at loci that Geiger (1982) has determined as being usually highly polymorphic in the Pieridae, such as got2. The fact that no diagnostic loci were found between $C$. alfacariensis and $C$. hyale is not uncommon in Lepidoptera_ For instance, Aubert et al. (1997) also found 


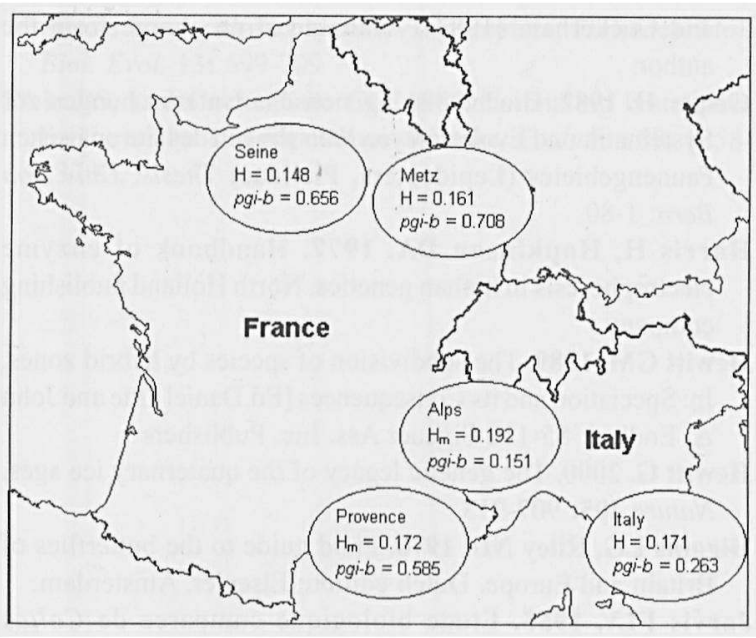

Fig. 2. Map of the localities where the populations of C. alfacariensis were sampled. Five main localities are shown, representing a single population with the exception of the Alps and Provence where three and four populations, respectively, were sampled. Within each circle average heterozygosity of 12 loci and the frequency of the $p g i-b$ allele are given. For the Provence and Alps the values are means of the three populations. $\mathrm{H}=$ heterozygosity of a single populations, $\mathrm{H}_{\mathrm{m}}=$ mean heterozygosity from more than one population.

no diagnostic loci between the sister species Papilio machaon and $P$. hospiton.

Both Colias species, but especially $C$. hyale are known to be migrants (Higgins and Riley, 1970). This explains why both species maintain a panmictic population structure over a large geographical area with little genetic differentiation between the populations. This is also the case with the Monarch butterfly (Danaus plexippus) (Eanes and Koehn, 1978) famed for its migratory ability. Other species of North American Colias also show a high level of movements between patches of their habitat (Watt et al., 1977).

The loss of genetic variation in C. hyale and its preference for high humidity conditions suggest that it may represent one of the many examples of northern split-off species that evolved from species that were able to survive the periods of glaciation in ice-free areas of the Mediterranean (Hewitt, 2000). Such populations were subsequently able to colonise the area left behind after the retreating ice sheet.

Split-offs usually result in reduced genetic variation coupled with independent evolution to sub- specific or specific status (Marchi et al., 1996). Populations at the northern edge of their range would be able to expand, usually via long-distance dispersal and rapidly colonize the newly available habitat allowing the best-adapted hybrid genomes to spread. These repeated colonising and founding events would eventually lead to a loss of alleles and thus to homozygosity. Many European and North American species show a lower genetic diversity in their northern populations (Hewitt, 2000). The same holds for other northern species, for example, the Dall sheep, Ovis dalli, only has a heterozygosity of 0.015 compared to an average of 0.041 for 184 mammalian taxa Hewitt (1989). Exactly such a pattern in levels of genetic variability can be found between $C$. alfacariensis and $C$. hyale. Not only does $C$. hyale have a lower genetic diversity than C. alfacariensis, but also Northern populations of $C$. alfacariensis have lower levels of heterozygosity.than southern populations. The loss of heterozygosity in this and other Northern species is argued to be due to repeated fluctuation of ice fronts, which will cause a series of shifts in the periglacial range of the species involved. Range changes and consequently changes in population size provide evidence for a general loss of heterozygosity in northern species compared to southern species. This can further be predicted for subdivided species with extensive North-South ranges, depending on the life history and population dynamics of the species involved.

For the southern populations, the temporal predictability of a suitable habitat patch should decrease the rate of extinction, making the colonisation of other suitable habitat patches unnecessary for the continued survival of the species in a particular area. Such decreases in extinction probably would be associated with lower gene flow (Liebherr, 1988).

Selection at $p g i$ has been demonstrated in a number of Colias species and PGI allozyme polymorphisms occur in parallel among many Colias species (Watt et al., 1996). In different American Colias complexes lowland and alpine groups have genotypes that display major functional differences, related to energy, allowing predictions about flight performance and fitness consequences which have been tested and confirmed (Watt et al., 1996; Watt, 
1992). PGI polymorphs of Colias taxa may have diverged from an ancestral polymorphism and have been maintained till today (Watt et al., 1996).

Males of kinetically favoured pgi genotypes show greater flight capacity, survivorship, and overall mating success. There is also active female choice in selecting these favoured genotypes, where favoured males have an even greater advantage in mating older, more discriminating females than they do in mating previously unmated less discriminating females (Watt et al., 1986). A similar selection might be occurring in $C$. alfacariensis, but interestingly enough not in its sister species $C$. hyale. As in the American Colias species the main difference in the PGI locus among $C$. alfacariensis populations is between the alpine populations of France and the high elevation population in Italy and the low-lying populations in the Provence and Northern France.

\section{Acknowledgements}

We wish to thank Leon Rayjymann and Wil van Ginkel for help in the lab. Barbra Schütt and Filipo Fabiani provided help with field collections.

\section{References}

Aubert J, Barascud B, Descimon H, Michel F. 1997. Ecology and genetics of interspecific hybridization in the swallowtails, Papilio hospiton Géné and $\mathbf{P}_{\mathbf{x}}$ machon $\mathrm{L}_{\mathrm{x}}$, in Corsica (Lepídoptera: Papilionidae). Biological Journal of the Linnean Society, 60: 467-492

Berger LA, Fontaine M. 1947. Une espece meconue du genre Colias F. Lambillionea XLVII 11-12: 91-111

Brunton CFA. 1998. The evolution of ultraviolet patterns in European Colias butterflies (Lepidoptera, Pieridae): a phylogeny using mitochondrial DNA. Heredity 80: 611-616

Descimon H. 1994(5). Colias hyale ( $\left.\mathrm{L}_{s}\right)$ : une espèce en voie de disparition? Alexanor 18: 440-442

Dutreix C. 1980. Étude des deux espèces affines Colias hyale Linné et Colias alfacariensis Verity [Lepidoptera, Pieridae]. Alexanor 11: 297-316

Eanes WF, Koehn RK. 1978. An analysis of genetic structure in the monarch butterfly, Dañus plexippus L. Evolution 32: 784-797

Ellis WN 1994. Theta version 2.2. A program for the Macintosh computer for the analysis of population structure and estimation of gene flow levels based on the methods of Weir and Cockerham (1984). Available at no charge from the author.

Geiger H. 1982. Bíochemisch-genetísche Untersuchungen zur Systematik und Evolution von Weisslingen des Europäischen Faunengebietes (Lepidoptera, Pieridae) Thesis, Univ von Bem: 1-80

Harris H, Hopkinson DA. 1977. Handbook of enzyme electrophoresis in human genetics. North Holland publishing company

Hewitt GM. 1989. The subdivision of species by hybrid zones. In: Speciation and its Consequences [Ed.Daniel Otte and John A. Endler]: 85-110 Sinauer Ass. Inc. Publishers

Hewitt G. 2000. The genetic legacy of the quaternary ice ages. Nature 405: 907-913

Higgins LG, Riley ND. 1970. Field guide to the butterflies of Britain and Europe. Dutch edition: Elsevier, Amsterdam.

Jarvis FLV. 1955. Etude biologique comparee de Colias alfacariensis (Verity) et de Colias hyale (L.) Lambillionea $L V, 3-4: 28-34$ and 5-6: 37-50

Lewis OT, Thomas CD, Hill JK, Brookes MI, Crane TPR, Graneau YA, Mallet JLB, Rose OC. 1997. Three ways of assessing metapopulation structure in the butterfly Plebejus argus. Ecological Entomology 22: 283-293

Liebherr JK. 1988. Gene flow in ground beetles (Coleoptera: Carabidae) of differing habitat preference and flight-wing development. Evolution 42: 129-137

Marchỉ A, Addis Exposito Hermosa V, and Crnjar R. 1996. Genetic divergence and evolution of Polyommatus corridon gennargenti (Lepidoptera: Lycaenidae) în Sardinia. Heredity 77: $16-22$

Menken SBJ, Herrebout WM, Wiebes JT. 1992. Small ermine moths (Yponomeuta): their host relations and evolution. Annu. Rev. Entomol. 37: 41-66.

Peterson AT, Soberón J, Sănchez-Cordero V. 1999. Conservation of ecological niches in evolutionary time. Science 285: 1265-1267

Raijmann LEL, VanGinkel WE, Heckel DG, Menken SBJ. (1997). Inheritance and linkage of isozymes in Yponomeuta padellus (Lepidoptera, yponomeutidae). Heredity 78: 645-654

Ritchie MG, Phillips SDF. 1998. The genetics of sexuals isolation. In: Endless Forms: species and speciation. Oxford University Press. P 470: 291-308

Statistica for Windows (version 5, StatSoft Inc.).

Tilman D. 2000 Causes, consequences and ethics of biodiversity. Nature 405: 208-211

Watt WB, Chew FS, Snyder LRG, Watt AG, Rothschild DE. 1977. Population structure of pierid butterflies. I. Numbers and movements of some montane Colias species. Oecologia 27:1-27.

Watt WB, Carter PA, Donahue K. 1986. Females' choice of "good genotypes" as mates is promoted by an insect mating system. Science 233: $1187-1190$

Watt WB. 1992, Eggs, enzymes, and evolution: natural genetic variants change insect fecundity. PNAS 89: 10608-10612

Watt WB, Donohue K, and Carter PA. 1996. Adaptation at specife loci. VI. Divergence vs. parellelism of polymorphic allozymes in molecular function and fitness-component 
effects among Colias species (Lepidoptera, Pieridae). $\mathrm{Mol}$. Biol. Evol. 13: 699-709

Weir BS, and Cockerham CC. 1984. Estimating F-statistics for the analysis of population structure. Evolution 38: 13581370.
Wright S. 1951. The genetical structure of populations. Annals of Eugenetics 15: 323-354

Accepted: 4 September 2002 